\title{
Study of $\mathrm{O}_{3} / \mathrm{S}_{2} \mathrm{O}_{8}{ }^{2-}$ Advanced Oxidation Processes (AOPs) for Removal of Dye Industrial Effluents
}

\author{
Che Zulzikrami Azner Abidin*, Fahmi Muhammad Ridwan, Ong Soon An, Abdul Haqi Ibrahim, Siti Nasuha Sabri, and Nur \\ Aqilah Razali
}

Water Research Group (WAREG), School of Environmental Engineering, Universiti Malaysia Perlis (UniMAP), Kompleks Pusat Pengajian Jejawi 3, 02600 Arau, Perlis, Malaysia

\begin{abstract}
This research was carried out to study the efficiency of $\mathrm{O}_{3} / \mathrm{S}_{2} \mathrm{O}_{8}{ }^{2-}$ system in removal of Reactive Red 120 (RR120) dye sample. Different operating parameter such as $\mathrm{pH}$, initial dye concentration and persulfate dosage were studied to evaluate the performance on removing colour and COD. The removal of colour and COD achieved higher efficiency at $\mathrm{pH} 7,100 \mathrm{mg} / \mathrm{L}$ of initial dye concentration and persulfate dosage of $5 \mathrm{~g} \mathrm{~S}_{2} \mathrm{O}_{8}{ }^{2-} / 1 \mathrm{~g}$ RR120. $\mathrm{O}_{3} / \mathrm{S}_{2} \mathrm{O}_{8}{ }^{2-}$ with the most effective conditions experienced effective decolourization and degradation of organic pollutants than $\mathrm{O}_{3}$ only. Furthermore, it achieved faster breakdown of azo bond and aromatic groups than $\mathrm{O}_{3}$ after treatment as observed with UV-Vis absorption spectra. The FT-IR analysis obtained new absorption peak that represents alkenes after 20 min of $\mathrm{O}_{3}$ treatment whereas mostly of the absorption bands of $\mathrm{O}_{3} / \mathrm{S}_{2} \mathrm{O}_{8}{ }^{2-}$ flattened.
\end{abstract}

\section{Introduction}

Water contamination is one of the problematic issues that cause much of the concern to the society all around the world. The largest polluters is an industry with the generation of large quantity of wastewater used in processing activities. Although a wide range of industries are responsible for releasing the hazardous pollutants into the water bodies, textile dyeing industries is one of the major concerns. The dyestuffs that release from dyeing and finishing process are often strong persistent colour, consists residues of dyes and chemicals such as high concentration of chemical oxygen demand (COD) and complex degradation materials which is environmentally unacceptable [1,2].

The technologies for removing wastewater containing dyes can be grouped into three types, which are biological, physical and chemical treatment. Each method has its own either technical or economic limitations. Typically, it is difficult to treat dye wastewater by conventional methods. It is because the azo dye molecules are often resistant to degradation due to the complex structured polymers that cause them nonbiodegradable [3, 4]. The conventional methods are often costly and create a disposal problem of precipitation formed after treatment processes [5]. For example, coagulation and flocculation processes with ferrous chloride or polymers have poor efficiency in removing highly soluble dyes and produce sludge problem [6]. Furthermore, ion exchange processes are unable to treat a variety types of dyes and high operating cost.
Therefore, advanced oxidation processes (AOPs) have been introduced that involving generation of sufficient quantity of free radicals such as hydroxyl radicals $\left({ }^{\bullet} \mathrm{OH}\right)$ or sulfate radicals $\left(\mathrm{SO}_{4}{ }^{--}\right)$to complete degrade the dye molecules $[7,8]$. The source of the radicals is either generated using single or combinations of different oxidants such as ozone, hydrogen peroxide, and titanium dioxide or UV radiation $[9,10]$. In $\mathrm{O}_{3} / \mathrm{S}_{2} \mathrm{O}_{8}{ }^{2-}$ system, the oxidation potential can be improved by using the sodium persulfate reagent during the ozonation [11]. While Ozone has played a part in increasing the $\cdot \mathrm{OH}$, which will help to initiate the $\mathrm{SO}_{4}{ }^{\bullet-}$ by activating the persulfate [12]. Both ${ }^{\bullet} \mathrm{OH}$ and $\mathrm{SO}_{4}{ }^{\bullet-}$ in $\mathrm{O}_{3} / \mathrm{S}_{2} \mathrm{O}_{8}{ }^{2-}$ system play an important role in the degradation of COD and colour. In this system, it has some operational advantages over the limitations of the general AOPs such as high potential in decolourization, degradation, mineralization and no sludge produces. Additionally, ozonation is costly cause by short life-time [13]. Hence, by employing $\mathrm{O}_{3} / \mathrm{S}_{2} \mathrm{O}_{8}{ }^{2-}$ in oxidation process will effectively reduce the cost, it is because less amount of ozone is apply to the treatment process.

In this study, the objective is to evaluate the performance of $\mathrm{O}_{3}$ and $\mathrm{O}_{3} / \mathrm{S}_{2} \mathrm{O}_{8}{ }^{2-}$ in terms of decolourization and degradation of RR120 dye sample, and characterized the change of functional group before and after the treatment. Next, to evaluate the effect of operating parameters on the treatment performance.

\footnotetext{
* Corresponding author: zulzikrami@unimap.edu.my
} 


\section{Methodology}

\subsection{Materials}

The analytical grade dye used was Reactive Red 120 (RR120) $\left(\mathrm{C}_{44} \mathrm{H}_{24} \mathrm{C}_{12} \mathrm{~N}_{14} \mathrm{Na}_{6} \mathrm{O}_{20} \mathrm{~S}_{6}\right)$, obtained from SigmaAldrich. Figure 1 shows the molecular structure of RR120. The persulfate dosage was prepared by Sodium Persulfate $\left(\mathrm{Na}_{2} \mathrm{~S}_{2} \mathrm{O}_{8}\right)$ obtained from $\mathrm{HmbG}$ chemical. The $\mathrm{pH}$ of the solution was adjusted using either $0.1 \mathrm{~N}$ $\mathrm{NaOH}$ or $0.1 \mathrm{~N} \mathrm{HCl}$ to raise or to lower the $\mathrm{pH}$ upon decolourization and degradation.

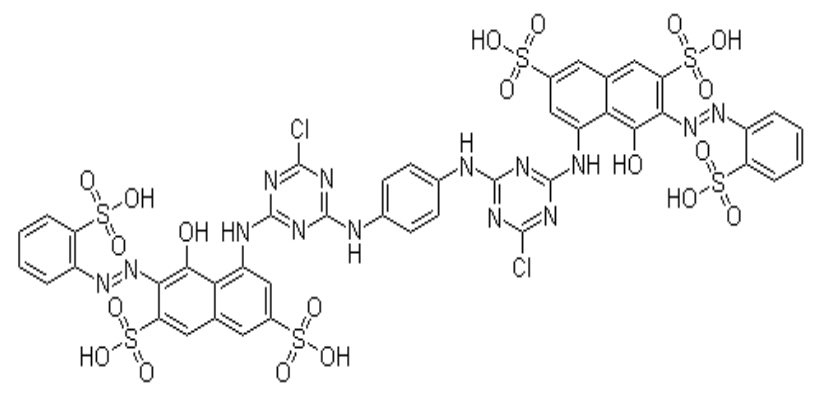

Fig. 1. Molecular structure of the RR120

\subsection{Methods}

Ozonation experiments were set up using a pure oxygen tank, ozone generator, ozone reactor, and glass reactor (2 $\mathrm{L}) . \mathrm{O}_{3}$ generator will produce $2.53 \mathrm{mg} / \mathrm{mL}$ of ozone flow rate and continuously introduces through a porous fritted diffuser, followed by the $5 \mathrm{~min}$ of aeration to remove residual ozone. The excess ozone is destroyed in a $2 \%$ KI solution. Figure 2 shows the schematic diagram of the experimental setup. The experimental setup of the $\mathrm{O}_{3} / \mathrm{S}_{2} \mathrm{O}_{8}{ }^{2-}$ process are same as the $\mathrm{O}_{3}$ process, but with the different persulfate dosage were added gradually to the $2 \mathrm{~L}$ dye sample that determined from $\mathrm{S}_{2} \mathrm{O}_{8}{ }^{2-} / \mathrm{RR} 120$ ratio $\left(1 / 1,2 / 1,3 / 1,4 / 1\right.$ and $\left.5 \mathrm{~g} \mathrm{~S}_{2} \mathrm{O}_{8}{ }^{2-} / 1 \mathrm{~g} \mathrm{RR} 120\right)$. The experiments were carried out with different operational conditions, which are initial dye conditions (100, 300 and $500 \mathrm{mg} / \mathrm{L})$, initial $\mathrm{pH}(3,5,7,9$ and 11) and contact

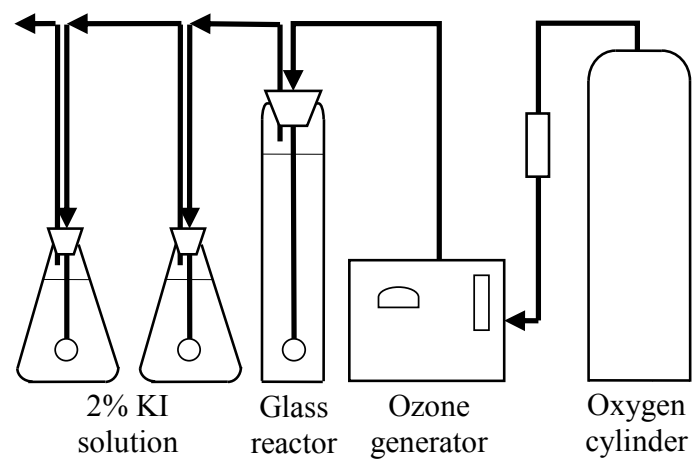

time $(0,1,2,3,4,5,10,15$ and $20 \mathrm{~min})$.

Fig. 2. Schematic diagram of experimental setup

\subsection{Analytical Methods}

Ozone flow rate was determined by starch-iodide method. The $\mathrm{pH}$ was measured by the Hanna Instruments HI $2211 \mathrm{pH}$ meter. COD analysis was based on procedure of Standard Methods for the Examination of Water and Wastewater: Closed reflux, colorimetric method [14]. The decolourization and degradation of the absorbing materials are measured by using HITACHI UV-Vis U-2810 spectrophotometer at wavelengths ranging from 800$200 \mathrm{~nm}$ with $10 \mathrm{~mm}$ quartz cell. The maximum visible region $\left(\lambda_{\max } 535 \mathrm{~nm}\right)$ was employed as a base to follow the RR120 decolourization. The change in functional groups of the dye samples was determine using PerkinElmer Spectrum 400 FT-IR spectrophotometer over the range of 4,000-650 $\mathrm{cm}^{-1}$. The dye sample were first dehydrated at $65^{\circ} \mathrm{C}$ to evaporate completely all of the organic solvent before FT-IR analysis.

\section{Results and Discussion}

The comparison of decolourization and mineralization of RR120 for both treatments method are based on the optimum operating parameter, where the most favourable condition to achieve highest removal

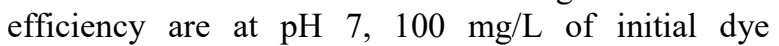
concentration and persulfate dosage of $5 \mathrm{~g} \mathrm{~S}_{2} \mathrm{O}_{8}{ }^{2-} / 1 \mathrm{~g}$ $\mathrm{RR} 120$ for $\mathrm{O}_{3} / \mathrm{S}_{2} \mathrm{O}_{8}{ }^{2-}$ system. The ozone flow rate was maintained at $2.53 \mathrm{mg} / \mathrm{mL}$.

\subsection{Decolourization}

Figure 3 shows colour removal of $\mathrm{O}_{3}$ and $\mathrm{O}_{3} / \mathrm{S}_{2} \mathrm{O}_{8}{ }^{2-}$. It can be seen that $\mathrm{O}_{3} / \mathrm{S}_{2} \mathrm{O}_{8}{ }^{2-}$ achieved higher removal efficiency compared to $\mathrm{O}_{3}$ only. It can be explained by $\mathrm{O}_{3} / \mathrm{S}_{2} \mathrm{O}_{8}{ }^{2-}$ has both $\cdot \mathrm{OH}$ and $\mathrm{SO}_{4}{ }^{\bullet-}$ attacks at the same time to break down the organic contaminants compared to only $\cdot \mathrm{OH}$ in ozonation. $\mathrm{SO}_{4}{ }^{\bullet-}$ have strong oxidation potential $(2.5-3.1 \mathrm{~V})$ as $\bullet \mathrm{OH}(1.8-2.7 \mathrm{~V})$ which both are capable to break the molecular structure of the dye [14].

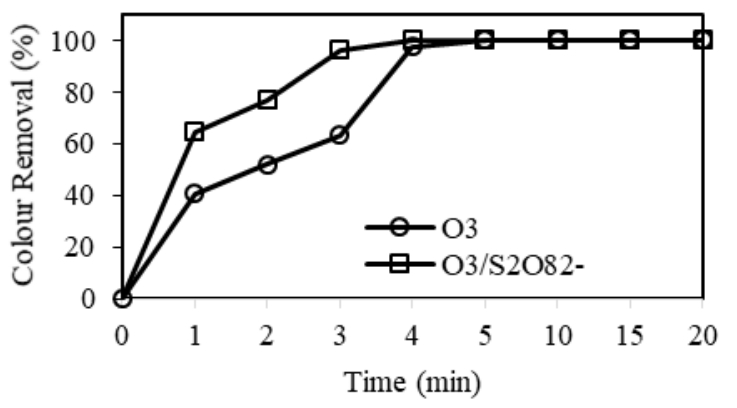

Fig. 3. Colour removal of $\mathrm{O}_{3}$ and $\mathrm{O}_{3} / \mathrm{S}_{2} \mathrm{O}_{8}{ }^{2-}$

Figure 4 shows the UV-Vis spectra of $\mathrm{O}_{3}$ and $\mathrm{O}_{3} / \mathrm{S}_{2} \mathrm{O}_{8}{ }^{2-}$ treatment. It can be seen that the intensity of absorbance was reduced sharply within $20 \mathrm{~min}$ of treatment time for $\mathrm{O}_{3} / \mathrm{S}_{2} \mathrm{O}_{8}{ }^{2-}$, which represents the cleavage of azo bond and resulting in decolourization. 
On the other hand, the benzene and naphthalene ring are connected to the azo bond at 212 and $298 \mathrm{~nm}$ in the UV region also showed greatly reduced with $\mathrm{O}_{3} / \mathrm{S}_{2} \mathrm{O}_{8}{ }^{2-}$ treatment. By comparison, although the degradation ability of organic pollutants by $\mathrm{O}_{3}$ is effective, but it is slowly degraded than $\mathrm{O}_{3} / \mathrm{S}_{2} \mathrm{O}_{8}{ }^{2-}$. This may be due to the fact that $\mathrm{O}_{3} / \mathrm{S}_{2} \mathrm{O}_{8}{ }^{2-}$ presences of extra oxidants to attack against the aromatic ring of target compounds, and indirectly will enhance the degradation ability of organic contaminants due to its higher oxidizing effect.

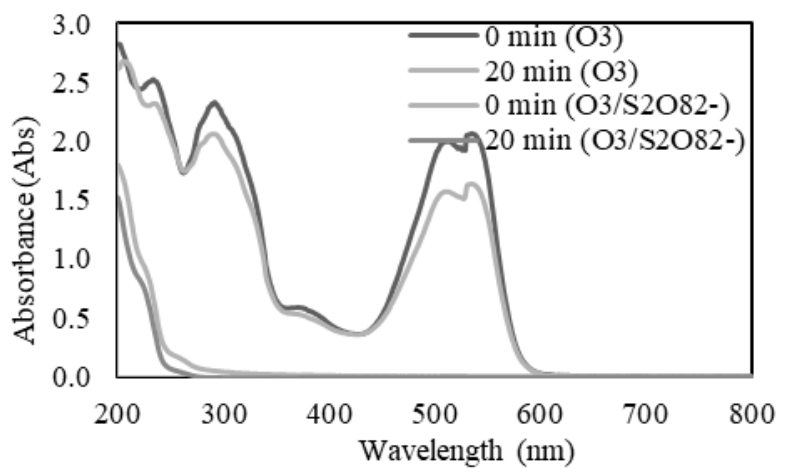

Fig. 4. UV-Vis spectra of $\mathrm{O}_{3}$ and $\mathrm{O}_{3} / \mathrm{S}_{2} \mathrm{O}_{8}{ }^{2-}$

\subsection{COD Removal}

Figure 5 shows the $\mathrm{COD}$ removal of $\mathrm{O}_{3}$ and $\mathrm{O}_{3} / \mathrm{S}_{2} \mathrm{O}_{8}{ }^{2-}$. It can be seen that $\mathrm{O}_{3} / \mathrm{S}_{2} \mathrm{O}_{8}{ }^{2-}$ achieved better removal efficiency than $\mathrm{O}_{3}$ only as experienced by colour removal. However, COD removal shows slowly increasing as compared with colour removal. It is due to the fact that as the oxidation continued, the fraction of available organic compounds that have highly selective for oxidized will reduces, and the remaining recalcitrant organic molecules are difficult to treat [2]. Therefore, it demands longer treatment time or presents of extra oxidant such as $\mathrm{H}_{2} \mathrm{O}_{2}$ or $\mathrm{Na}_{2} \mathrm{~S}_{2} \mathrm{O}_{8}$ reagent to improve the efficiency to oxidize the remaining inert organic compounds. Although both treatment methods are effective in decolourization, but it is insufficient to oxidize the small organic molecules.

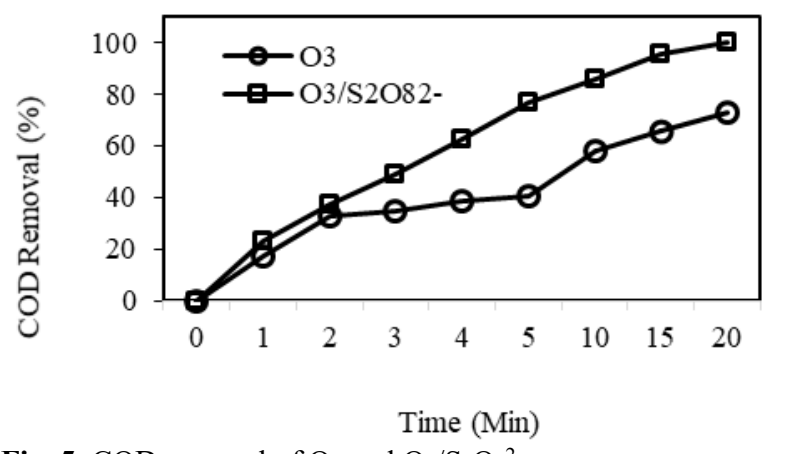

Fig. 5. $\mathrm{COD}$ removal of $\mathrm{O}_{3}$ and $\mathrm{O}_{3} / \mathrm{S}_{2} \mathrm{O}_{8}{ }^{2-}$

\subsection{FT-IR Analysis}

Figure 6 shows the FT-IR spectra for $\mathrm{O}_{3}$ and $\mathrm{O}_{3} / \mathrm{S}_{2} \mathrm{O}_{8}{ }^{2-}$ treatment. It can be seen that the peak initially located at 1483 and $1417 \mathrm{~cm}^{-1}$ was reduced after 20 min with $\mathrm{O}_{3}$ and $\mathrm{O}_{3} / \mathrm{S}_{2} \mathrm{O}_{8}{ }^{2-}$ treatment, respectively. It is indicated that the azo bond has been degraded with the treatment time. At 0 min, $\mathrm{O}_{3} / \mathrm{S}_{2} \mathrm{O}_{8}{ }^{2-}$ shown mostly of the peak becomes smoothness after addition of sodium persulfate reagent compared to the ozonation that have many bands and peaks. It can be explained by the naturally occurring persulfate anion in the solution can degraded the organic pollutants before ozonation [16]. At 20 min of ozonation, although most of the peak intensities were reduced, but there has still had many bands that can be characterized as individual functional group. By comparing with $\mathrm{O}_{3} / \mathrm{S}_{2} \mathrm{O}_{8}{ }^{2-}$ treatment, even though there still have sulphonic groups located at $1152 \mathrm{~cm}^{-1}$, but overall it can be seen that the trend was smoothness.

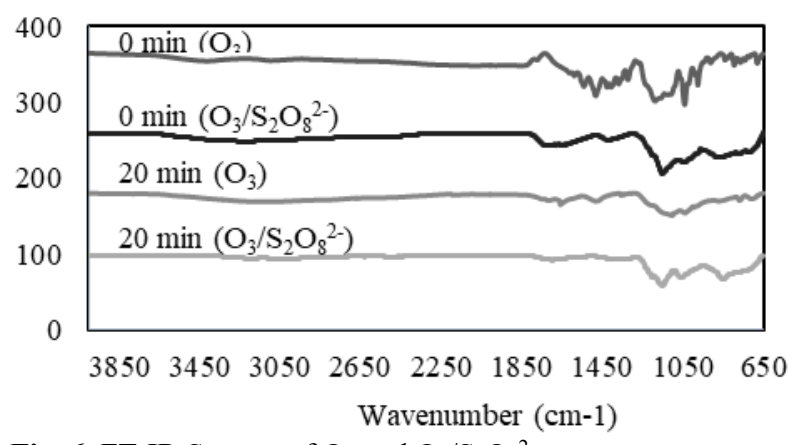

Fig. 6. FT-IR Spectra of $\mathrm{O}_{3}$ and $\mathrm{O}_{3} / \mathrm{S}_{2} \mathrm{O}_{8}{ }^{2-}$

\subsection{Effect of Initial pH}

The $\mathrm{pH}$ values were reduced steadily from $\mathrm{pH} 7$ to 3 after treatment processes. It may due to the degradation of aromatic compounds are forming the acidic intermediate products such as alkenes and carboxylic acid $[15,8,17]$. This statement was supported by the findings as shown at FT-IR analysis.

Furthermore, it can be seen that both methods achieved completely decolourization from $\mathrm{pH} 3$ to 5 , and further to 11 . On the other hand, COD removal for both treatments was increased from $\mathrm{pH} 3$ to 5, and sharply rose to 7 . Finally, slowly increased from $\mathrm{pH} 7$ to 11 . This may explained by reaction between molecular ozone and organic pollutant is the predominant mechanism at low $\mathrm{pH}$ and took over by radicals at high $\mathrm{pH}$ [18]. Therefore direct oxidation is less effective than indirect oxidation due to radicals have stronger oxidizing power than ozone molecule. Thus, $\mathrm{pH} 7$ was selected as the best $\mathrm{pH}$ as increasing of $\mathrm{pH}$ has little effect on the concentration.

Subsequently, no observed of significant increases of removal efficiency when increasing of $\mathrm{pH}$ from 7 to 11 . It may be due to carbonate ions $\left(\mathrm{CO}_{3}{ }^{2-}\right)$ and bicarbonate ions $\left(\mathrm{HCO}^{3-}\right)$ produced in large amount at $\mathrm{pH}$ greater than 9 and become hydroxyl radical scavengers by interfering the existing reaction and compete for hydroxyl radicals with the target pollutant.

\subsection{Effect of Initial Dye Concentration}

Figure 7 and 8 shows the colour and COD removal rate at 100 and $500 \mathrm{mg} / \mathrm{L}$ dye concentration for $\mathrm{O}_{3}$ and $\mathrm{O}_{3} /$ $\mathrm{S}_{2} \mathrm{O} 82$ - treatment. It can be seen that both graphs have a higher efficiency of reduction at lower initial dye 
concentration than higher concentrations. In fact, increasing the dye concentration will increase the fraction of non-biodegradable and toxic components in the solutions. Thus, the removal rate for colour and COD will be lower for higher initial dye concentrations. It is because the ratio of ozone molecules to dye molecules in the solutions decreases with increases of the dye concentration [7, 19]. Therefore, more oxidants needed to be consumed in order to completely degrade the refractory pollutants.

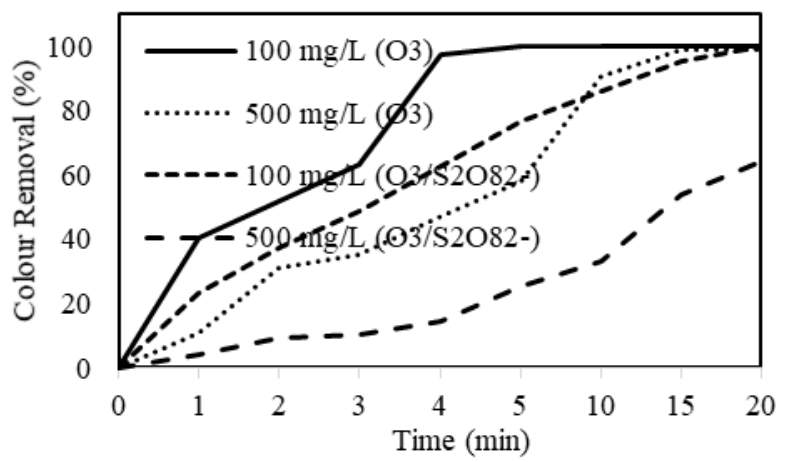

Fig. 7. Colour removal at different initial dye concentration

However, by comparing Figure 7 and 8, it shows better decolourization and degradation of $\mathrm{O}_{3} / \mathrm{S}_{2} \mathrm{O}_{82}$ - than $\mathrm{O}_{3}$ alone. Thus, it can be explained by the $\mathrm{O}_{3} / \mathrm{S}_{2} \mathrm{O}_{82}$ system have extra oxidants such as persulfate molecular or sulfate radicals which either directly or indirectly to enhance the performance in decolourization and degradation.

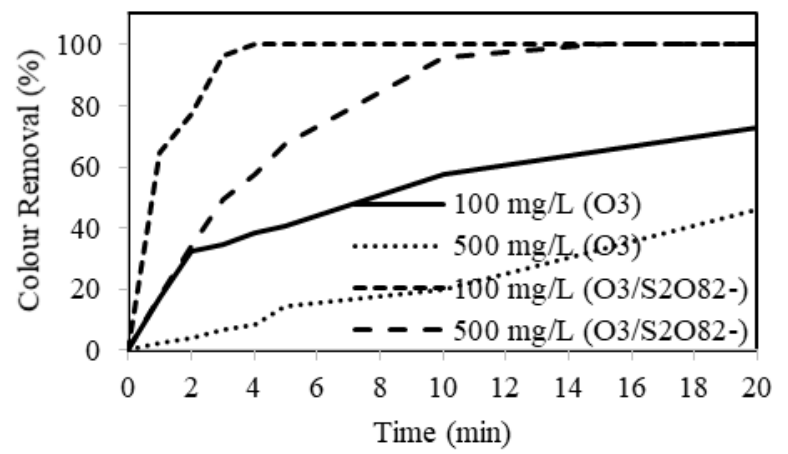

Fig. 8. COD removal at different initial dye concentration

\subsection{Effect of Persulphate Dosage}

Figure 9 and 10 shows the colour and COD removal of $\mathrm{O}_{3} / \mathrm{S}_{2} \mathrm{O}_{82}$ - system. It can be seems that persulfate dosage of $5 \mathrm{~g} \mathrm{~S}_{2} \mathrm{O}_{82} / 1 \mathrm{~g}$ achieved highest removal efficiency for both colour and COD removal. Thus, it was chosen as the best dosage due to it have the higher percentage of reduction among others dosage tested.

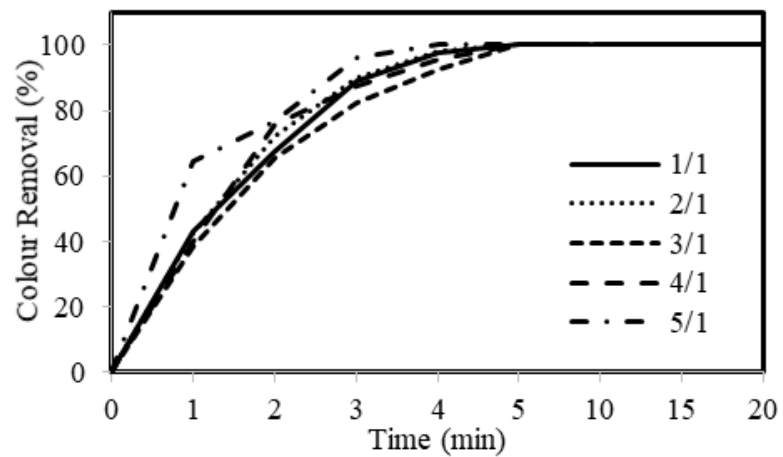

Fig. 9. Colour removal at different persulfate dosage

From the results obtained, it can be concluded that as persulfate dosage increases, there will have a fast reaction rate that leads to the formation of sulfate radicals. It will result in higher decolourization and degradation efficiency when sufficient quantities of radicals were maintained in the reaction. However, excess dosage of persulfate in the solutions- will affect the performance of sulfate radicals system and inhibit the reaction. Hence, the overall efficiency will decrease.

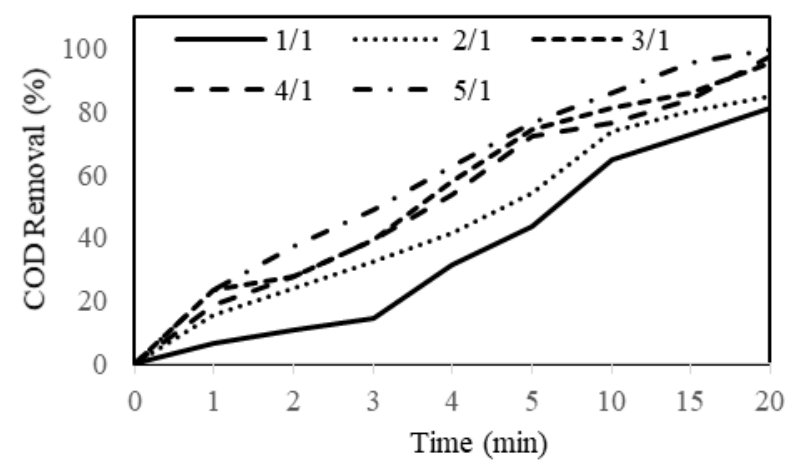

Fig. 10. COD removal at different persulfate dosage

\section{Conclusion}

Overall, the $\mathrm{O}_{3} / \mathrm{S}_{2} \mathrm{O}_{8}{ }^{2-}$ system obtained better decolourization and degradation of RR120 than $\mathrm{O}_{3}$ only based on the best operating parameters, where the most favorable condition to achieve highest removal efficiency are at $\mathrm{pH} 7,100 \mathrm{mg} / \mathrm{L}$ of initial dye concentration and persulfate dosage of $5 \mathrm{~g} \mathrm{~S}_{2} \mathrm{O}_{8}{ }^{2-/ 1} \mathrm{~g}$ $\mathrm{RR} 120$ for $\mathrm{O}_{3} / \mathrm{S}_{2} \mathrm{O}_{8}{ }^{2-}$ system. This statement was supported by the analysis of UV-Vis spectra and FT-IR. It can be seen that the degradation of the absorption peak of $\mathrm{O}_{3} / \mathrm{S}_{2} \mathrm{O}_{8}{ }^{2-}$ is faster than the $\mathrm{O}_{3}$. Furthermore, mostly of the absorption bands and peaks was flattened as compared to $\mathrm{O}_{3}$ which still have many bands that can characterized as individual functional groups.

The authors gratefully acknowledge the financial support of the Ministry of Higher Education, Malaysia through the Fundamental Research Grant Scheme (FRGS/1/2015/TK02/UNIMAP/02/4). 


\section{References}

1. M. Siti Zuraida, C.R. Nurhaslina, K.H.K. Hamid, Removal of synthetic dyes from wastewater by using bacteria, Lactobacillus delbruckii, International Refereed Journal of Engineering and Science, 2, 5, 1-7 (2013)

2. A. Yasar, N. Ahmad, M.N. Chaudhry, M.S.U. Rehman, A.A.A. Khan, Ozone for color and COD removal of raw and anaerobically biotreated combined industrial wastewater, Polish J. of Environ. Stud., 16, 2, 289-294 (2007)

3. M. Ahmadi, J. Behin, A.R. Mahnam, Kinetics and thermodynamics of peroxydisulfate oxidation of Reactive Yellow 84, J. of Saudi Chem. Soc., 20, 6, 644-650 (2013)

4. S.H. Lin, C.M. Lin, Treatment of textile waste effluents by ozonation and chemical coagulation, Water Res, 27, 12, 1743-1748 (1993)

5. A. Çelekli, M. Yavuzatmaca, H. Bozkurt, Binary adsorption of reactive red 120 and yellow 81 on spirogyra majuscule, Middle East J Sci Res, 13, 6, 740-748 (2013)

6. N. Azbar, T. Yonar, K. Kestiglu, Comparison of various advanced oxidation processes and chemical treatment methods for COD and colour removal from a polyester and acetate fiber dyeing effluent, Chemosphere, 55, 1, 35-43 (2004)

7. D.M. Yang, B. Wang, H.Y. Ren, J.M. Yuan, Effects and mechanism of ozonation for degradation of sodium acetate in aqueous solution, Water Sci. Eng., 5, 2, 155-163 (2012)

8. S. Cortez, P. Teixeira, R. Oliveira, M. Mota, Evaluation of Fenton and ozone-based advanced oxidation processes as mature landfill leachate pretreatments, J Environ Manage., 92, 3, 749-755 (2011)

9. L.G. Covinich, D.I. Bengoechea, R.J. Fenoglio, M.C. Area, Advanced oxidation processes for wastewater treatment in the pulp and paper industry: a review, American Journal of Environmental Engineering, 4, 3, 56-70 (2014)

10. S.S. Kalra, S. Mohan, A. Sinha, G. Singh, Advanced oxidation processes for treatment of textile and dye wastewater: A review, International Conference on Environmental Science and Development, 4, 271-275 (2011)

11. S.S. Abu Amr, H.A. Aziz, M.N. Adlan, Optimization of stabilized leachate treatment using ozone / persulfate in the advanced oxidation process, Waste Manage., 33, 6, 1434-1441 (2013)

12. S.S. Abu Amr, H.A. Aziz, M.N. Adlan, J.M.A. Alkasseh, Effect of ozone and ozone/persulfate processes on biodegradable and soluble characteristics of semi-aerobic stabilized leachate, Environ. Prog. Sustainable Energy, 33, 1, 184-191 (2014)
13. D.B. Hayelom, The potential of dyes removal from textile wastewater by using different treatment technology, a review, International Journal of Environmental Monitoring and Analysis, 2, 6, 347353 (2014)

14. APHA-AWWA-WEF, Standard Methods for the Examination of Water and Wastewater, $21^{\text {st }}$ edn, APHA, Washington, DC (2005)

15. H.A. Aziz, S.S. Abu Amr, M.J.K. Bashir, Evaluation and optimization of various ozone- based advanced oxidation processes in the treatment of stabilized landfill leachate. Aust. J. Basic Appl. Sci., 9, 4, 9-19 (2015)

16. A.R. Padmanabhan, Novel simultaneous reduction / oxidation process for destroying organic solvents. Thesis (Msc). Worcester Polytechnic Institute (2008)

17. M.P.G.D.S. Lucas, Application of advanced oxidation processes to wastewater treatment. Thesis $(\mathrm{PhD})$. University of Tras-os-Montes and Alto Douro (2009)

18. T. Poznyak, R. Tapia, I. Chairez, Effect of $\mathrm{pH}$ to the Decomposition of Aqueous Phenols Mixture by Ozone, J. Mex. Chem. Soc., 50, 1, 28-35 (2006)

19. A.R. Tehrani-Bagha, F.L. Amini, Decolourization of reactive dye by UV-enhanced ozonation, Prog. Color Colorants Coat., 3, 1, 1-8 (2010) 